\title{
Non-junctional Cx32 mediates anti-apoptotic and pro-tumor effects via epidermal growth factor receptor in human cervical cancer cells
}

\author{
Yifan Zhao ${ }^{1,2,6}$, Yongchang Lai ${ }^{1,6}$, Hui Ge ${ }^{3,6}$, Yunquan Guo ${ }^{4,6}$, Xue Feng $^{3}$, Jia Song ${ }^{3}$, Qin Wang ${ }^{1}$, Lixia Fan ${ }^{1}$, Yuexia Peng ${ }^{1}$, Minghui Cao ${ }^{2}$, \\ Andrew L Harris ${ }^{5}$, Xiyan Wang ${ }^{*, 3}$ and Liang Tao ${ }^{*, 1}$
}

The role of connexin proteins (Cx), which form gap junctions (GJ), in progression and chemotherapeutic sensitivity of cervical cancer ( $\mathrm{CaCx}$ ), is unclear. Using cervix specimens ( $313 \mathrm{CaCx}, 78$ controls) and $\mathrm{CaCx}$ cell lines, we explored relationships among Cx expression, prognostic variables and mechanisms that may link them. In $\mathrm{CaCx}$ specimens, Cx32 was upregulated and cytoplasmically localized, and three other $\mathrm{Cx}$ downregulated, relative to controls. Cx32 expression correlated with advanced FIGO staging, differentiation and increased tumor size. In $\mathrm{CaCx}$ cell lines, $\mathrm{Cx} 32$ expression suppressed streptonigrin/cisplatin-induced apoptosis in the absence of functional GJ. In CaCx specimens and cell lines, expression of Cx32 upregulated epidermal growth factor receptor (EGFR) expression. Inhibition of EGFR signaling abrogated the anti-apoptotic effect of Cx32 expression. In conclusion, upregulated $\mathrm{C} \times 32$ in $\mathrm{CaCx}$ cells produces anti-apoptotic, pro-tumorigenic effects in vivo and vitro. Abnormal $\mathrm{C} \times 32$ expression/localization in $\mathrm{CaCx}$ appears to be both a mechanism and biomarker of chemotherapeutic resistance.

Cell Death and Disease (2017) 8, e2773; doi:10.1038/cddis.2017.183; published online 11 May 2017

Connexin proteins (Cx) compose vertebrate gap junctions (GJ), which modulate essential cellular processes including electrical coupling, proliferation, differentiation and apoptosis. ${ }^{1,2}$ Consistent with the idea of "contact growth inhibition' originally proposed in the 1960s,, ${ }^{3,4}$ GJ and Cx have been widely accepted as tumor suppressive; loss of GJ is characteristic of malignancy. ${ }^{5-7}$ In malignant tumor cells, transfection with $\mathrm{Cx}$ enhances radiotherapy/chemotherapyinduced apoptosis in a GJ-dependent manner (toxic 'bystander effect').,8,9 Our recent work demonstrated that GJ facilitated cisplatin-induced apoptosis in cancerous cells, but suppressed apoptosis in normal cells. ${ }^{10,11}$ Besides, other studies have shown that expression of $\mathrm{Cx}$ can induce cancer cell growth inhibition and apoptosis independent of GJ function. ${ }^{12-14}$ It was also reported that cytoplasmic Cx exerts pro-tumor effects during metastasis in many cancers, including colorectal, gastric, breast, prostate and liver, ${ }^{15-19}$ and conducts chemoresistance in glioblastoma. ${ }^{20,21}$ In contrast, it was recently reported that $\mathrm{Cx}$ suppressed metastasis of liver cancer cells. ${ }^{22}$ Therefore, the role of Cx expression, independent of GJs, in cancer pathogenesis is still controversial.

Worldwide, morbidity and mortality of cervical cancer (CaCx) rank fourth in cancers of women. ${ }^{23,24}$ It is well accepted that human papillomavirus (HPV) infection is highly correlated with cervical cancer. ${ }^{25,26}$ Loss of GJIC and reduction of expression of Cx26, Cx30 and Cx43 were described in HPV-infected dysplastic cervical epithelial cells. $^{27,28}$ However, these reports are based primarily on in vitro or animal experiments; data on expression and distribution of $\mathrm{Cx}$ in human $\mathrm{CaCx}$ specimens are rare. The relationships among $\mathrm{Cx}$ expression, GJ function and carcinogenesis in $\mathrm{CaCx}$ are still largely unknown.

The present study was designed to reveal the role and mechanism of $\mathrm{Cx}$ expression in $\mathrm{CaCx}$. A clinical-pathological investigation of four $\mathrm{Cx}$ isoforms (Cx26, Cx30, Cx32, and Cx43) was performed to detect their expression and distribution in normal cervix specimens and multiple grades of $\mathrm{CaCx}$. The main goal was to explore the contribution of $\mathrm{Cx}$ expression to pathogenesis of $\mathrm{CaCx}$ to expand diagnostic and therapeutic options. We also provide empirical evidence for a mechanism by which $\mathrm{Cx}$ expression may promote chemoresistance in $\mathrm{CaCx}$.

\section{Results}

Unlike other connexins, Cx32 is aberrantly upregulated and mislocalized in human $\mathbf{C a C x}$ tissue. Expression of Cx26, Cx30, Cx32 and Cx43 was analyzed in human specimens consisting of: Normal cervix $(n=78)$, CaCx FIGO stage I $(n=148)$, CaCx FIGO stage II $(n=165)$. In the CaCx

\footnotetext{
${ }^{1}$ Department of Pharmacology, Zhongshan School of Medicine, Sun Yat-Sen University, Guangzhou 510080, China; ${ }^{2}$ Department of Anesthesiology, Sun Yat-Sen Memorial Hospital, Sun Yat-Sen University, Guangzhou 510120, China; ${ }^{3}$ Tumor Research Institute, Xinjiang Medical University Affiliated Tumor Hospital, Urumqi, Xinjiang 830000, China; ${ }^{4}$ Department of Pathology, Xinjiang Medical University Affiliated Tumor Hospital, Urumqi, Xinjiang 830000 , China and ${ }^{5}$ Department of Pharmacology, Physiology and Neuroscience, New Jersey Medical School - Rutgers University, Newark, NJ 07103, USA

*Corresponding author: L Tao, Department of Pharmacology, Zhongshan School of Medicine, Sun Yat-Sen University, 74 Zhongshan 2nd Road, Guangzhou 510080, China. Tel: +86-20-8733-5468; Fax: +86-20-8733-2318; E-mail: taol@mail.sysu.edu.cn

or X Wang, Tumor Research Institute, Xinjiang Medical University Affiliated Tumor Hospital, 789 Suzhou Road, Urumqi, Xinjiang 830000, China. Tel: +86-99-1796-8111; Fax: +86-991-7968008; E-mail: wangxiyan2415@163.com

${ }^{6}$ These authors contributed equally to this work.

Received 20.10.16; revised 17.3.17; accepted 21.3.17; Edited by G Dewson
} 
a
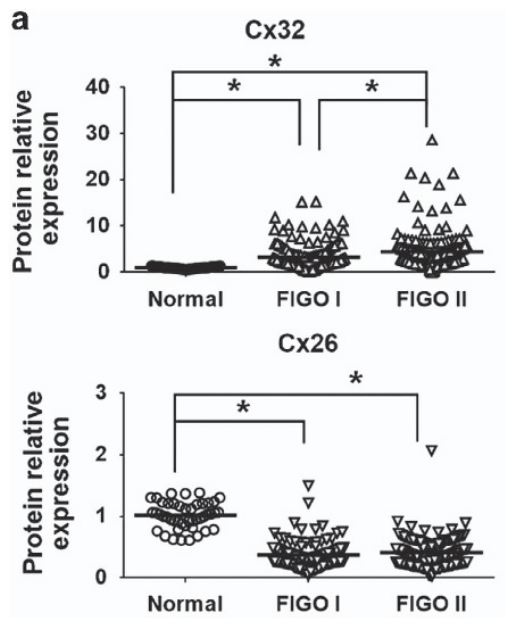

b

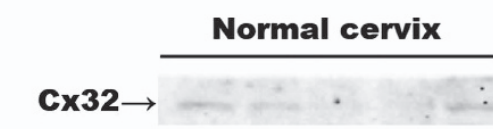

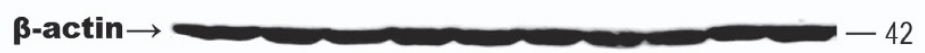

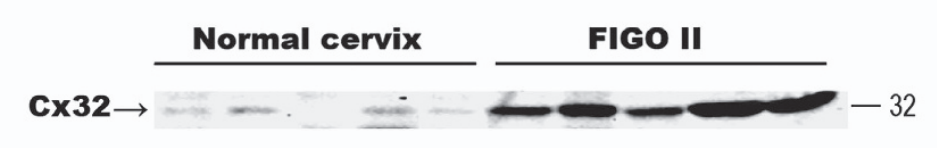

$\boldsymbol{\beta}$-actin $\rightarrow \longrightarrow-42$

C

Normal cervix

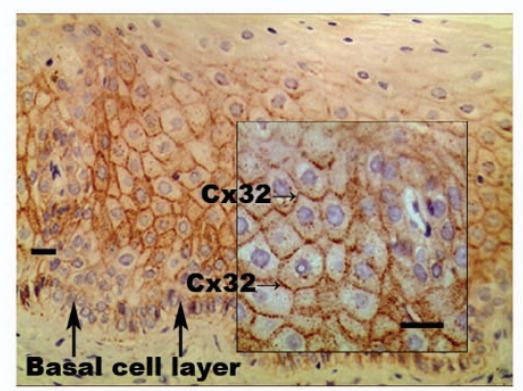

Cx32 found primarily in junctional membrane.

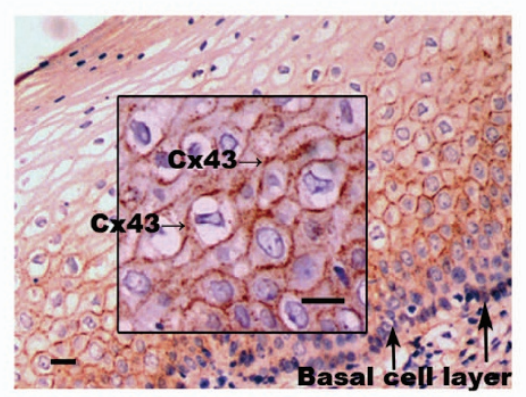

Cx43 found primarily in junctional membrane.

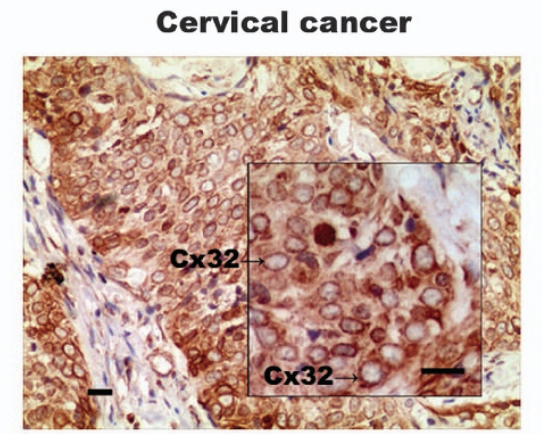

Cx32 found primarily in para-nuclea cytoplasm.

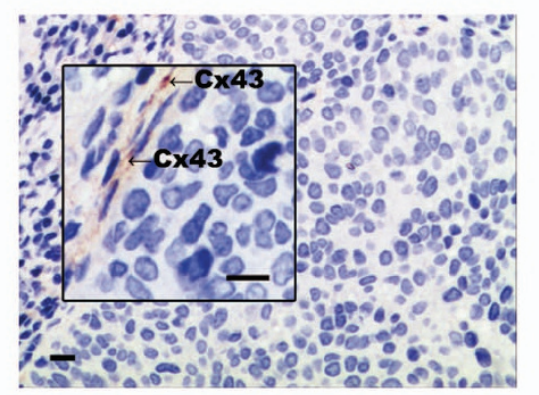

Cx43 rarely expressed.

Figure 1 (a) Expression of $\mathrm{C} \times 32, \mathrm{C} \times 26, \mathrm{C} \times 30$ and $\mathrm{C} \times 43$ in normal cervix and $\mathrm{CaCx}$ samples. Expression of $\mathrm{C} \times 26, \mathrm{C} \times 30$ and $\mathrm{C} \times 43$ was decreased in the cancer samples relative to control, while expression of Cx32 was markedly increased. (b) Western blots showing that expression of expression of Cx32 correlated with increased FIGO score. Data are shown for five samples in each category (c) Immunohistochemistry showing that $\mathrm{Cx} 32$ and $\mathrm{Cx} 43$ in normal cervix tissue were localized to junctional regions. In CaCx cells, Cx32 aberrantly aggregated in para-nuclear cytoplasm and Cx43 was rarely expressed. (Scale bar: $20 \mu \mathrm{m}) .{ }^{*} P<0.05$ 
Table 1 Protein expression of four connexin isotypes in normal cervix and different FIGO stage cervical cancer specimens

\begin{tabular}{lccc}
\hline & $\begin{array}{c}\text { Normal cervix } \\
(\boldsymbol{n}=\mathbf{7 8})\end{array}$ & $\begin{array}{c}\text { FIGO I } \\
(\boldsymbol{n}=\mathbf{1 4 8 )}\end{array}$ & \multicolumn{1}{c}{$\begin{array}{c}\text { FIGO II } \\
(\boldsymbol{n}=\mathbf{1 6 5})\end{array}$} \\
\hline Cx32 & $1.015 \pm 0.213$ & $3.262 \pm 2.915^{\mathrm{a}}$ & $4.434 \pm 4.450^{\mathrm{ab}}$ \\
Cx43 & $1.017 \pm 0.212$ & $0.316 \pm 0.319^{\mathrm{a}}$ & $0.285 \pm 0.357^{\mathrm{a}}$ \\
Cx26 & $1.016 \pm 0.212$ & $0.376 \pm 0.199^{\mathrm{a}}$ & $0.413 \pm 0.222^{\mathrm{a}}$ \\
Cx30 & $1.016 \pm 0.213$ & $0.389 \pm 0.221^{\mathrm{a}}$ & $0.414 \pm 0.211^{\mathrm{a}}$
\end{tabular}

Abbreviation: FIGO, Federation International of Gynecology and Obstetrics

${ }^{a}$ Comparing with Normal cervix, $P<0.05$

${ }^{\mathrm{b}}$ Comparing with FIGO I, $P<0.05$

P.S.: Data were presented as mean \pm S.D.

samples, expression of Cx26, Cx30 and Cx43 was significantly reduced (Figure 1a and Table 1). However, the mean of Cx32 expression in $\mathrm{CaCx}$ specimens was higher than that in normal cervix specimens, and the degree of upregulation correlated with advanced FIGO stages (Figures 1a, b and Table 1) (FIGO I versus Normal, $P<0.001$; FIGO II versus Normal, $P<0.001$; FIGO I versus FIGO II, $P=0.0088$ ). To our knowledge, this is the first evidence that $\mathrm{Cx} 32$, often considered a tumor suppressive factor, is highly expressed in $\mathrm{CaCx}$ tissue, and is specifically upregulated relative to expression in normal cervical tissue.

The cellular localization Cx32 was examined by immunohistochemistry (IHC) in normal cervix $(n=9)$ and $\mathrm{CaCx}$ $(n=41)$ samples. In normal cervix specimens, Cx32 was found essentially exclusively in plasma membrane in $88.8 \%$ (8/9) of the samples (Figure 1c, upper left). In dramatic contrast, in Cx32 was found only in the cytoplasm of $92.7 \%$ (38/41) of CaCx specimens (Figure 1c, upper right) For comparison, in normal cervix samples, Cx43 was found in plasma membrane in 9/9 cases, but it was detected at very low levels or not at all in CaCx specimens (low levels in 21/41 cases; not detected in 20/41 cases) (Figure 1c, lower), consistent with the western blot results. This downregulation of $\mathrm{Cx} 43$ in $\mathrm{CaCx}$ specimens was consistent with previous reports. ${ }^{7,26}$ The above results indicate that $\mathrm{Cx} 32$ is specifically upregulated in human $\mathrm{CaCx}$ cells and is retained in cytoplasm and so cannot contribute to gap junction formation.

High expression of $\mathrm{Cx} 32$ is correlated with advanced FIGO stage, augmented tumor size and poorer differentiation in human $\mathbf{C a C x}$. On the basis of relative expression levels of $\mathrm{Cx} 32$ in the $313 \mathrm{CaCx}$ samples relative to that in controls (mean for all CaCx samples was 3.86 times that in controls), the $\mathrm{CaCx}$ data were divided into groups of high expression ( $>3.86, n=196)$ and low expression $(<3.86$, $n=117)$. A large number of clinical-pathologic variables of the two groups were compared (Table 2). These were: age, ethnic group, FIGO stage, maximum diameter of tumor, lymph nodes metastasis, tumor emboli, whole-layer infiltration, pelvic nerve invasion, and differentiation, recurrence in 3 year and HPV infection. Statistically significant positive correlations were found between high Cx32 expression and FIGO stage $(P=0.010)$, tumor maximum diameter $(P=0.023)$ and differentiation $(P=0.22)$. These results show that high $\mathrm{Cx} 32$ expression in $\mathrm{CaCx}$ specimens is specifically
Table 2 Relationship between Cx32 expression and clinical variables

\begin{tabular}{|c|c|c|c|}
\hline & $\begin{array}{l}\text { Low expression } \\
(<3.86, n=196)\end{array}$ & $\begin{array}{l}\text { High expression } \\
(>3.86, n=117)\end{array}$ & $P$-value \\
\hline $\begin{array}{l}\text { Age } \\
\text { Ethnic }\end{array}$ & $47.79(46.49,49.09)$ & $50.16(48.59,51.73)$ & N.S. \\
\hline $\begin{array}{l}\text { Han } \\
\text { Uyghur }\end{array}$ & $\begin{array}{r}108(34.5 \%) \\
88(28.1 \%)\end{array}$ & $\begin{array}{l}58(18.5 \%) \\
59(18.8 \%)\end{array}$ & N.S. \\
\hline FIGO stage & $\begin{array}{r}104(33.2 \%) \\
92(29.4 \%)\end{array}$ & $\begin{array}{l}44(14.1 \%) \\
73(23.3 \%)\end{array}$ & 0.010 \\
\hline $\begin{array}{l}\text { Maximum } \\
\text { diameter } \\
\text { of tumor }(\mathrm{cm})\end{array}$ & 3.08 (2.88, 3.29) & $4.04(3.62,4.46)$ & 0.023 \\
\hline $\begin{array}{l}\text { Lymph node } \\
\text { metastasis }\end{array}$ & & & \\
\hline $\begin{array}{l}\text { Positive } \\
\text { Negative }\end{array}$ & $\begin{array}{r}41(13.1 \%) \\
155(49.5 \%)\end{array}$ & $\begin{array}{l}22(7 \%) \\
95(30.4 \%)\end{array}$ & N.S. \\
\hline $\begin{array}{l}\text { Tumor emboli } \\
\text { Positive } \\
\text { Negative }\end{array}$ & $\begin{array}{r}48(15.3 \%) \\
148(47.3 \%)\end{array}$ & $\begin{array}{l}37(11.8 \%) \\
80(25.6 \%)\end{array}$ & N.S. \\
\hline $\begin{array}{l}\text { Differentiation } \\
\text { Poorly } \\
\text { Moderately/ } \\
\text { well }\end{array}$ & $\begin{array}{c}50(16 \%) \\
146(46.6 \%)\end{array}$ & $\begin{array}{l}45(14.4 \%) \\
72(23 \%)\end{array}$ & 0.022 \\
\hline $\begin{array}{l}\text { Whole-layer } \\
\text { infiltration }\end{array}$ & & & \\
\hline $\begin{array}{l}\text { Positive } \\
\text { Negative }\end{array}$ & $\begin{array}{l}55(17.6 \%) \\
141(45 \%)\end{array}$ & $\begin{array}{l}43(13.7 \%) \\
74(23.6 \%)\end{array}$ & N.S. \\
\hline $\begin{array}{l}\text { Pelvic nerve } \\
\text { invasion }\end{array}$ & & & \\
\hline $\begin{array}{l}\text { Positive } \\
\text { Negative }\end{array}$ & $\begin{array}{c}8(2.6 \%) \\
188(60.1 \%)\end{array}$ & $\begin{array}{c}5(1.6 \%) \\
112(35.8 \%)\end{array}$ & N.S. \\
\hline $\begin{array}{l}\text { Recurrence in } 2 \\
\text { years }\end{array}$ & & & \\
\hline $\begin{array}{l}\text { Positive } \\
\text { Negative }\end{array}$ & $\begin{array}{c}1(0.3 \%) \\
195(62.3 \%)\end{array}$ & $\begin{array}{c}2(0.6 \%) \\
115(36.7 \%)\end{array}$ & N.S. \\
\hline HPV infection & & & \\
\hline $\begin{array}{l}\text { Positive } \\
\text { Negative } \\
\text { Not detected }\end{array}$ & $\begin{array}{c}144(46 \%) \\
17(5.4 \%) \\
35(11.2 \%)\end{array}$ & $\begin{array}{l}86(27.5 \%) \\
13(4.2 \%) \\
18(5.8 \%)\end{array}$ & N.S. \\
\hline
\end{tabular}

Abbreviation: N.S., not significant

P.S.: Mean of Cx32 relative expression: 3.86 , total 313 cases. Parametric data were presented as mean and $95 \%$ confidence interval

associated with deteriorated FIGO stage, augmented tumor size and poorer differentiation.

Overexpression of Cx32 suppressed apoptosis of HeLa and SiHa cells only when GJ function was inhibited. The above results suggest a correlation between Cx32 expression and advanced tumor stage. To address whether the enhanced Cx32 level was causative, Cx32 expression was induced in the HeLa-Cx32 cell line (see Materials and Methods) with doxycycline. Induction of Cx32 expression was accompanied by increased GJ intercellular communication (GJIC), which was inhibited by the GJ inhibitor 2APB $(50 \mu \mathrm{M})$ (Figures $2 \mathrm{a}$ and b). Treatment of the Cx32expressing HeLa cells with streptonigrin (SN) $(1 \mu \mathrm{M} ; 6 \mathrm{~h})$ induced massive apoptosis, consistent with prior work. ${ }^{29}$ 
a HeLa-Cx32

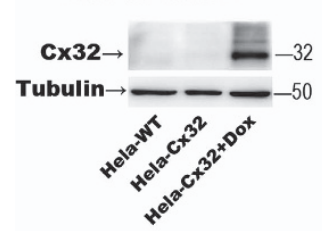

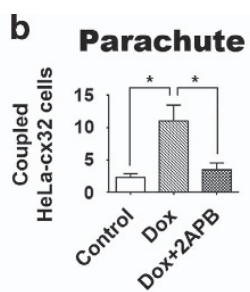

\section{e}

C High density culture
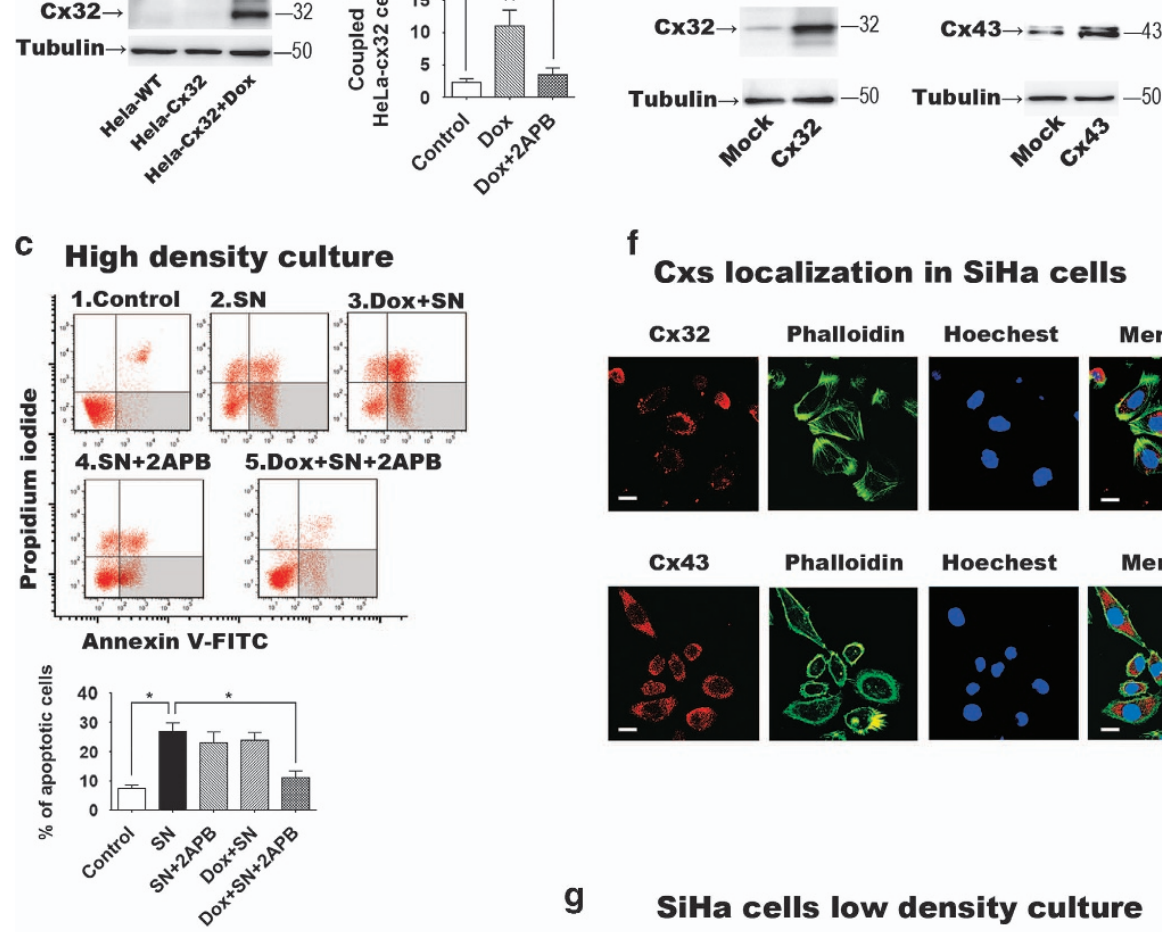

f

Cxs localization in SiHa cells
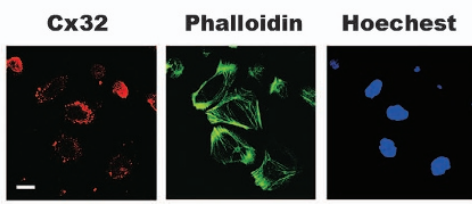

Merge
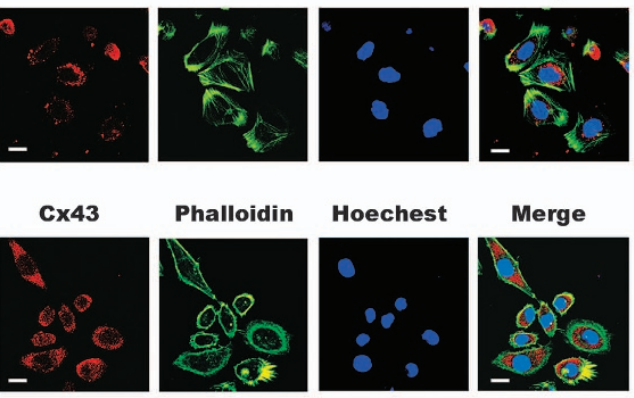

Merge

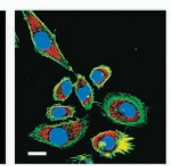

g SiHa cells low density culture
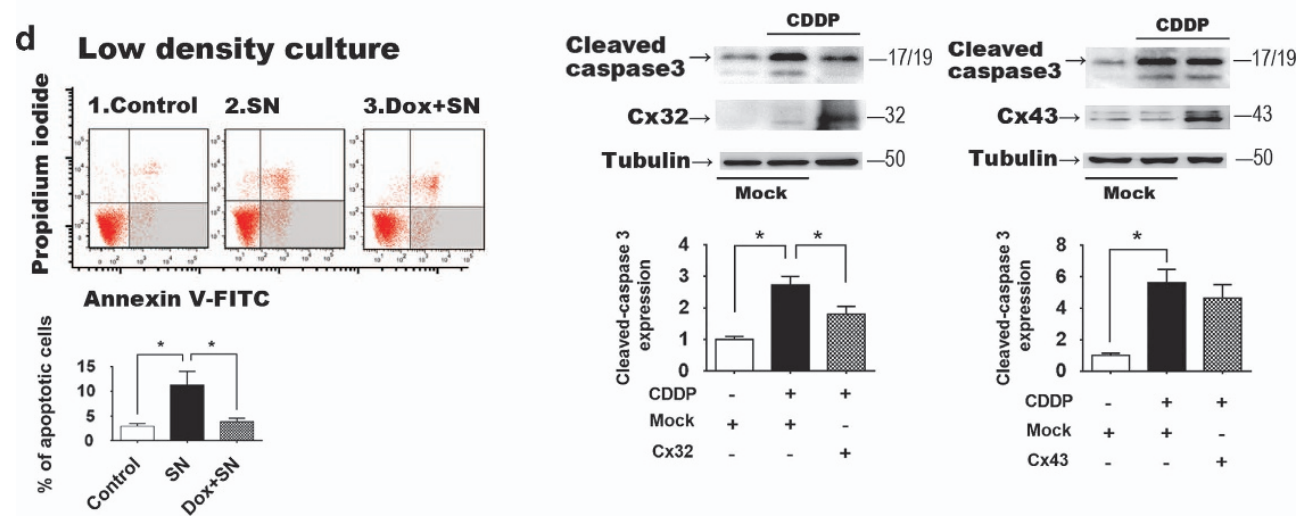

Figure 2 (a) Western blot showing induction of Cx32 expression in the HeLa-Cx32 cell line after $48 \mathrm{~h}$ doxycycline treatment $(n=5)$. (b) Demonstration of induction of GJIC following induction of Cx32 expression, and inhibition of GJIC with application of the GJ inhibitor 2APB $(50 \mu \mathrm{M})(n=5)$. GJIC was assessed by parachute assay of dye coupling (c) Effects of functional gap junctions on apoptosis induced by streptonigrin (SN, $1 \mu \mathrm{M})$. In high-density cultures, which allow formation of GJ, SN-induced apoptosis was suppressed when GJ function was inhibited by 2APB $(n=7)$. 2APB had no effect in the absence of induced Cx32 expression. Neither doxycycline (Dox, to induce Cx32 expression) nor 2APB (GJ inhibition) suppressed SN-induced apoptosis when applied alone. (d) When GJ formation was physically inhibited by low-density culture, expression of Cx32 suppressed SN-induced apoptosis $(n=5)$. (e) Transient transfection of SiHa cells induced expression of $\mathrm{Cx32}$ or $\mathrm{Cx43}(n=3)$. ( $\mathrm{f})$ In transfected SiHa cells, both $\mathrm{Cx32}$ and Cx43 mainly localized in cytoplasm $(n=3$, scale bar $=10 \mu \mathrm{m})$. (g) Expression of $\mathrm{Cx32}$, but not Cx43, in SiHa cells suppressed apoptosis induced by cisplatin (CDDP, $10 \mu \mathrm{M})$ under low-density culture $(n=3)$. Error bar: standard error. ${ }^{\star} P<0.05 ; n=1$ represents an independent cell culture

However, SN-induced apoptosis was significantly suppressed by treatment of the Cx32-expressing HeLa cells with the GJ inhibitor 2APB $(n=7, P=0.0011)$. Neither doxycycline nor 2APB alone suppressed apoptosis (Figure 2c). Also, 2APB did not alter SN-induced apoptosis in HeLa wild-type cells (cells not transfected with the tet-ON Cx32 promotor; Supplementary Data).

These results indicate that expression of $\mathrm{Cx} 32$ when GJ function is inhibited results in protection against $\mathrm{SN}$-induced apoptosis. To test the above hypothesis, Cx32-expressing
HeLa cells were grown in low-density culture, in which there was no opportunity for GJ formation. In this condition as well, in which GJ formation was inhibited physically rather than pharmacologically, increased Cx32 expression also significantly suppressed SN-induced apoptosis (SN versus Dox $+\mathrm{SN}, P=0.0379, n=5$ ) (Figure $2 \mathrm{~d}$ ). These results demonstrate that $\mathrm{Cx} 32$ expression in the absence of functional GJ-which is what is seen in the CaCx clinical samples, based on absence of $\mathrm{Cx32}$ in plasma membrane, suppresses SN-induced apoptosis. 

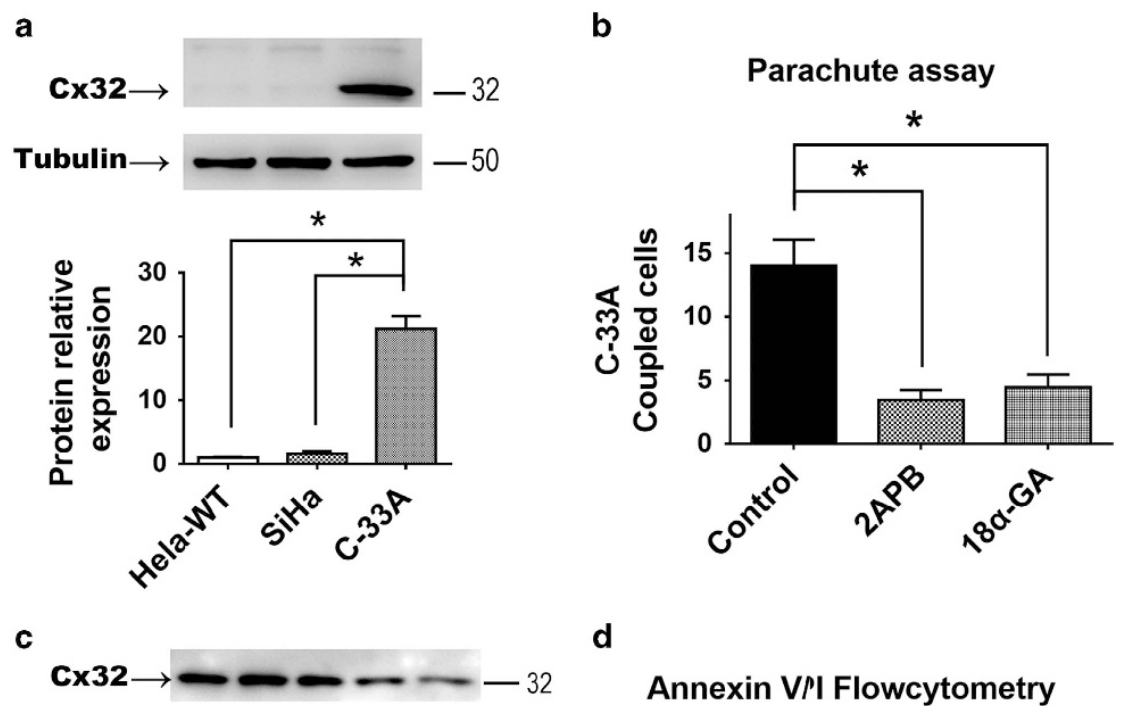

d

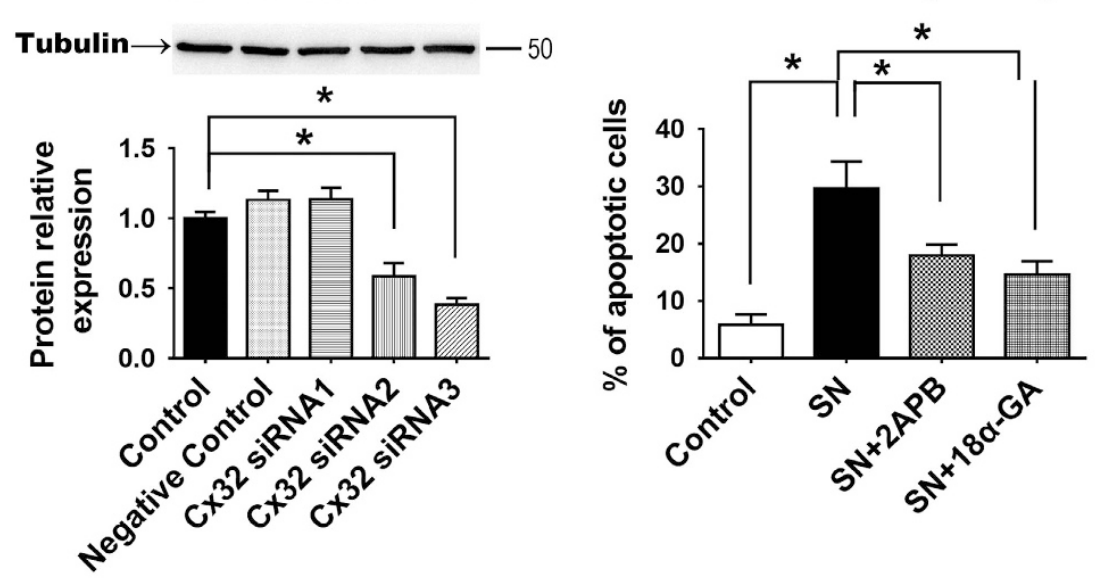

e Annexin V/PI Flowcytometry

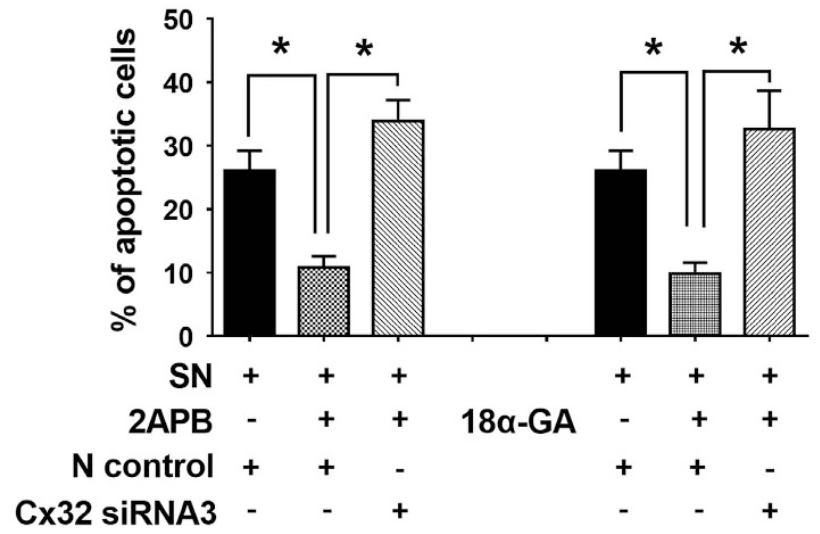

Figure 3 (a) C-33A cells endogenously express Cx32, unlike HeLa or SiHa cells $(n=3)$. (b) The endogenous GJIC of C-33A cells was abolished by gap junction inhibitors 2APB and 18 $\alpha$-GA $(n=3)$. (c) Western blot comparing effectiveness of three siRNAs in reducing expression of $\mathrm{C} \times 32$ in C-33A cells. $(n=3)$. (d) Suppression of SN-induced apoptosis by treatment with 2APB or $18 \alpha$-GA in C-33A cells $(n=7)$. (e) The anti-apoptotic effect of 2APB and 18 $\alpha$-GA in C-33A cells was reversed by Cx32 RNA interference $(n=5)$. Error bar: standard error. ${ }^{*} P<0.05 ; n=1$ represents an independent cell culture

To address whether this anti-apoptotic effect was specific for Cx32, we transiently transfected $\mathrm{SiHa}$ cells to express either Cx32 $(n=3, P=0.0042)$ or $\operatorname{Cx43}(n=3, \quad P=0.031)$ (Figure 2e). Exogenous gene expressed Cx32 and Cx43 both mainly localized in cytoplasm under confocal microscope in
$\mathrm{SiHa}$ cells from three independent cultures (Figure 2f). Lowdensity culture was used to fully inhibit GJ formation between these cells. Following $24 \mathrm{~h}$ treatment with cisplatin $(10 \mu \mathrm{M})$, apoptosis was assessed by expression of cleaved-caspase3. In this assay, expression of Cx32 significantly suppressed 
cisplatin-induced apoptosis $(P=0.031, n=3)$ as expected, but expression of $\mathrm{Cx} 43$ did not (Figure $2 \mathrm{~g}$ ). These results show both that the anti-apoptotic effect of Cx32 expression in the absence of GJ was not specific to HeLa cells, and that is was specific for $\mathrm{C} \times 32$ expression, as it could not be produced by expression of another common connexin, Cx43.

siRNA knockdown of endogenous Cx32 expression in C-33A cells reversed the anti-apoptotic effect of $G J$ inhibitors. C-33A cells endogenously express Cx32 and form functional GJ, unlike non-transfected HeLa and $\mathrm{SiHa}$ cells $(n=3, P<0.001)$ (Figure 3a). GJIC between C-33A cells is abolished by either 2APB or 18a-GA $(n=3, P<0.001)$ (Figure $3 b$ ). Consistent with the previous studies using HeLa and $\mathrm{SiHa}$ cells transfected to express $\mathrm{C} \times 32$, apoptosis of $\mathrm{C}-33 \mathrm{~A}$ cells was induced by $6 \mathrm{~h}$ SN $(1 \mu \mathrm{M})$ treatment, and was suppressed by 2 APB or $18 a-G A \quad(n=5, P=0.012)$ (Figure 3d) (2APB and 18-GA did not alter expression of Cx32 in C-33A cells; Supplementary Data). To knockdown the endogenous $\mathrm{Cx} 32$ expression in these cells, three different Cx32 siRNA sequences were tested for ability to reduce Cx32 expression; Cx32 siRNA sequence 3 (Cx32siRNA3) had the greatest efficacy $(n=3, P<0.001)$ (Figure $3 c$ ). Transfection of $\mathrm{C}-33 \mathrm{~A}$ cells with Cx32-siRNA3 reversed the anti-apoptotic effects of 2APB $(n=6, P<0.001)$ and 18a-GA $(n=6, P=0.0046)$ (Figure $3 e)$. This demonstrates that the endogenous $\mathrm{Cx} 32$, in the absence of GJ function, was responsible for the anti-apoptotic effect revealed by inhibition of GJ function by 2APB and 18a-GA. Thus, in three human cervical cell lines, Cx32 was shown to suppress apoptosis when GJ function or formation is inhibited.

Cx32 expression up-regulates EGFR and activates its downstream effectors Erk1/2 and Stat3. We found that in 30 cases of $\mathrm{CaCx}, \mathrm{Cx} 32$ expression was highly correlated with expression of EGFR ( $r=0.604, P=0.00041)$ (Figure 4a). EGFR expression at both protein and mRNA levels were significantly suppressed by Cx32-siRNA3 in C-33A cells $(n=3, P<0.001)$ (Figure 4b). Analogously, EGFR expression was augmented by induced expression of Cx32 in HeLaCx32 cells. Simultaneously, the downstream p-Erk1/2 $(n=3$, $P=0.040)$ and $p$-Stat3 $(n=3, P=0.044)$ were significantly upregulated (Figure 4c).

To gain insight into how $\mathrm{Cx} 32$ expression may affect EGFR expression, nuclear protein samples were obtained from normal and $\mathrm{CaCx}$ tissue, and assessed for presence of $\mathrm{Cx} 32$. The presence of $\mathrm{Cx} 32$ in nuclear protein samples was significantly greater from $\mathrm{CaCx}(n=10)$ than normal cervix samples $(n=5) \quad(P=0.0152)$. It has been reported that connexin may directly regulate the transcription of apoptosis regulators via a 'connexin responsive element' in the nucleus. $^{30}$ Elevation of nuclear $\mathrm{C} \times 32$ could provide a mechanism by which non-GJ Cx32 affects EGFR expression and the anti-apoptotic effect described above.

Cx32 exerts an anti-apoptotic effect via the EGFR pathway in $\mathbf{C a C x}$ cells. Three siRNA sequences targeted to EGFR expression were assessed in HeLa-Cx32 cells. The siRNA sequence 1 (EGFR-siRNA1) effectively suppressed
EGFR expression with or without induction of Cx32 expression ( $n=3, P<0.001$ ) (Figure 5a). Cx32 expression had the same anti-apoptotic effect under exposure of SN $(n=3$, $P<0.001)$ and 2APB $(n=3, P<0.001)$ as previously (apoptosis was detected by flow cytometry or cleaved-caspase 3 expression). However, when EGFR expression was inhibited by EGFR-siRNA1, the anti-apoptotic effect of Cx32 was reversed (Figures $5 b-d$ ). The same results were seen with application of two EGFR pathway inhibitors, erlotinib and afatinib. These results show that the EGFR pathway is an essential component of the Cx32-induced anti-apoptotic effect.

\section{Discussion}

Taken together, the results of the present study indicate that the specific upregulation and non-junctional localization of Cx32 in human $\mathrm{CaCx}$ cells contributes to tumor growth and chemoresistance. The results also suggest that in the context of chemotherapeutic exposure, Cx32 can have either proapoptotic effects (via GJIC) or anti-apoptotic effects (via cytosolic and potentially nuclear localization), with the latter effect involving the EGFR signaling pathway. Thus, the balance between junctional and cytosolic localization of Cx32 is likely to determine the overall effect.

Cx32 was specifically upregulated in human $\mathrm{CaCx}$ specimens, unlike three other connexins, which were downregulated. Elevated $\mathrm{Cx32}$ expression was associated with deteriorated FIGO stage, augmented tumor size and poorer differentiation. To our knowledge, this is the first clinicalpathological evidence showing that a $\mathrm{Cx}$ is highly expressed in $\mathrm{CaCx}$ cells. Previous reports indicated that other $\mathrm{Cx}$ are downregulated in $\mathrm{CaCx}, 6,28,31$ a finding reproduced here. However, the highly elevated $\mathrm{Cx} 32$ expression and its distribution in cytoplasm of $\mathrm{CaCx}$ cells have not been previously reported. Our in vitro studies of the effects of strong Cx32 expression in the absence of GJIC indicate that this key finding has important consequences for tumor biology and therapy: In the in vitro studies, Cx32 suppressed streptonigrin/ cisplatin-induced apoptosis only after GJ function was inhibited, either pharmacologically or physically. We speculate that due to the non-junctional localization of $\mathrm{Cx} 32$, the antiapoptotic effect is dominant in $\mathrm{CaCx}$ tissue. This finding can be a comprehensive explanation of the tumor promoting effect of Cx32 in our clinical-pathological studies. The reason for the non-junctional localization of the $\mathrm{Cx} 32$ in the $\mathrm{CaCx}$ cells remains unknown at this time, but may offer a point of therapeutic intervention.

Building on the novel finding of specific upregulation and non-junctional localization of Cx32 in the clinical samples, in vitro studies were utilized to comprehensively explore the effects of these parameters on chemoresistance and growth. Three human $\mathrm{CaCx}$ cell lines were used, each expressing (or not expressing) $\mathrm{Cx32}$ by a different mechanism (HeLa-Cx32: stable transfection with an inducible promotor; SiHa: transient transfection to express $\mathrm{Cx} 32$ or Cx43; C-33A: endogenous expression of $\mathrm{Cx} 32$ which could be suppressed by siRNA). These systems allowed us to manipulate Cx32 expression both up and down, in transfected and endogenously expressing in $\mathrm{CaCx}$ cells, and to independently manipulate $\mathrm{GJ}$ 


\section{a CaCx specimen}
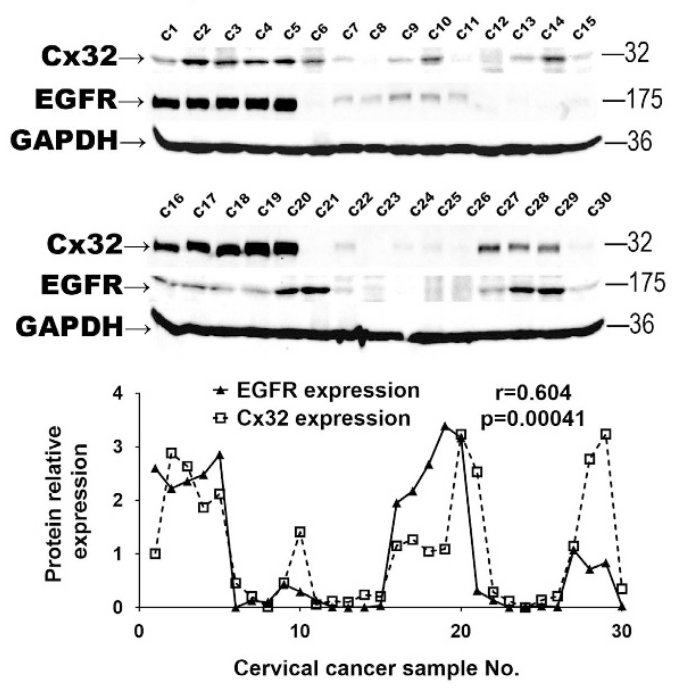

b

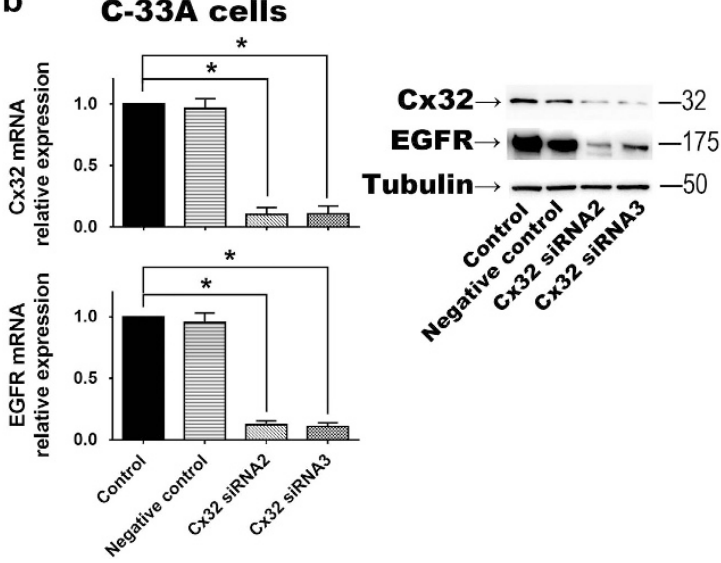

C HeLa-Cx32 cells
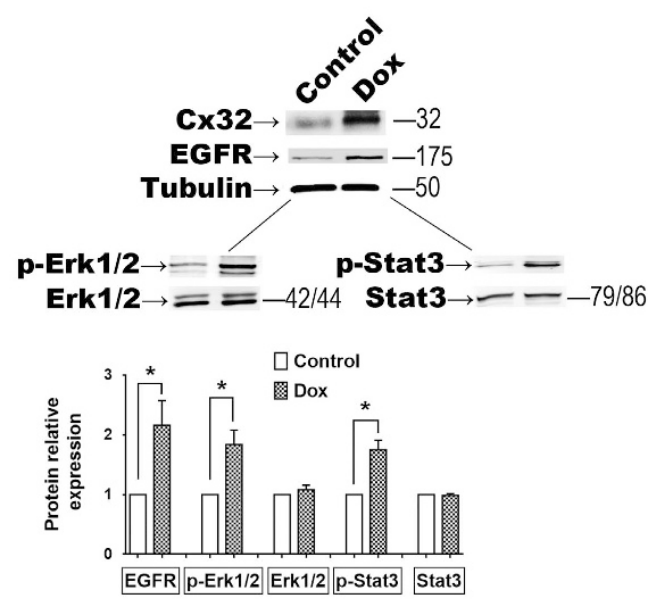

d Nuclear expression of $\mathrm{Cx} 32$
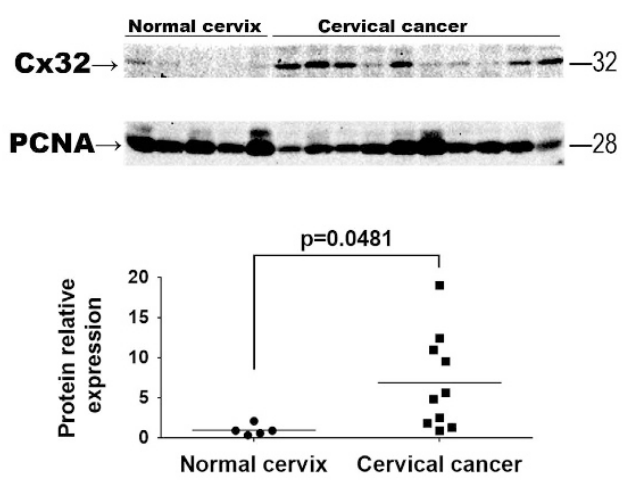

Figure 4 (a) In $30 \mathrm{CaCx}$ specimens, expression of EGFR was highly correlated with expression of $\mathrm{Cx32}(\mathrm{r}=0.604, P=0.00041)$. (b) In $\mathrm{C}$-33A cells, when Cx32 expression was inhibited by Cx32 siRNAs, EGFR expression was significantly suppressed $(n=3)$. (c) In HeLa-Cx32 cells, after induced Cx32 expression, EGFR was significantly increased and its downstream effectors p-Erk1/2 and p-Stat3 were upregulated $(n=3)$. (d) In nuclear protein samples, Cx32 expression in CaCx cells $(n=10)$ was higher than that in normal cervix cells $(n=5, P=0.0152)$. Error bar: standard error. ${ }^{\star} P<0.05 ; n=1$ represents an independent cell culture; $r$. Pearson correlation coefficient

formation/function by pharmacological and physical means. The results were consistent across all manipulations and systems: the presence of Cx32 not involved in GJs exerted a protective effect against chemotherapeutic agents.

The applied anti-tumor drugs induce apoptosis by an intrinsic pathway. ${ }^{32,33}$ GJs are well-known to facilitate intrinsic apoptosis via 'death signal' transmission among cancer cells. ${ }^{9,34,35}$ In the present study, Cx32 expression did not enhance streptonigrin-induced apoptosis in human $\mathrm{CaCx}$ cells, even though it suppressed apoptosis after 2APB inhibited the GJ. We infer that prior to GJ inhibition by 2APB, Cx32 expression exerted two opposing effects, a toxic bystander effect mediated by GJ, and an anti-apoptotic effect medicated by the intracellular accumulation of Cx32. In this case, it appears that these two effects counteracted each other to balance the change of apoptosis in 'Dox+SN' group, and that once the GJ-mediated toxic effect was eliminated by $2 A P B$, the protective effect was revealed. Notably, the antiapoptotic effect of Cx32 in CaCx cells was not reproduced by forced expression of $\mathrm{Cx} 43$, showing that the effect is specific for $\mathrm{Cx} 32$, the only connexin found to be upregulated in the CaCx tissue.

In other reports, independent of GJ, the ability of Cx to affect apoptosis varies for different $\mathrm{Cx}$ and different tissues. ${ }^{36}$ Although Cx composes GJ, recent studies have shown a variety of non-GJ-mediated effects of $\mathrm{Cx}$ in cancer cells. ${ }^{37,38}$ We found that $\mathrm{Cx} 32$ was more likely to be found in cell nuclei in $\mathrm{CaCx}$ cells than in controls. This result is in line with Dang's report regarding $\mathrm{Cx} 43$ nuclear localization in nucleus and its regulation of cancer cell viability. ${ }^{39}$ It was reported that in the nucleus Cx can interact with 'connexin responsive element' (CxRE) to modulate transcription of apoptosis-related proteins. ${ }^{30,40}$ Sulkowski and colleagues found that expression of Cx26 correlated with expression of insulin-like-growth factor I receptor (IGF-IR) in human colorectal cancer. ${ }^{41}$ Munoz also reported an interaction between Cx43 and EGFR signaling to induce chemoresistance against temozolomide in glioblastoma-multiforme cells. ${ }^{21}$ In line with the above 


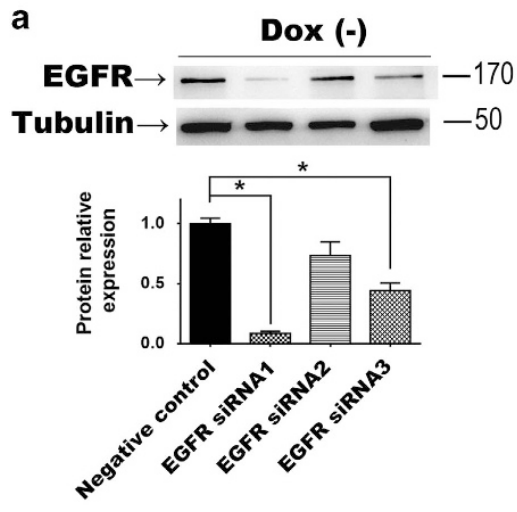

C

Exposure of SN+2APB

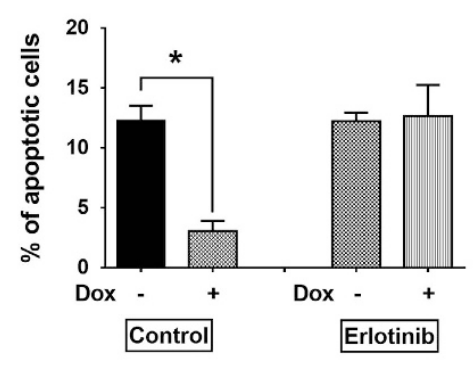

Dox (+)
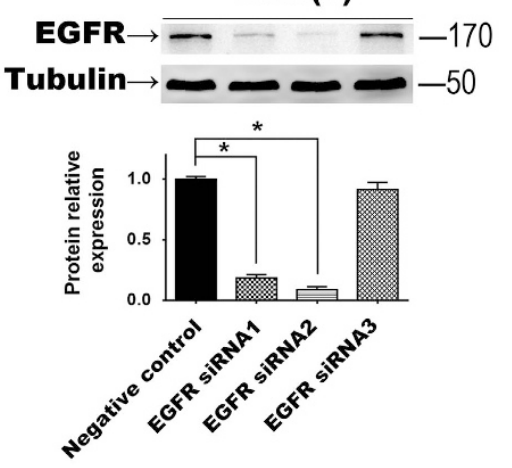

b

\section{Exposure of SN+2APB}

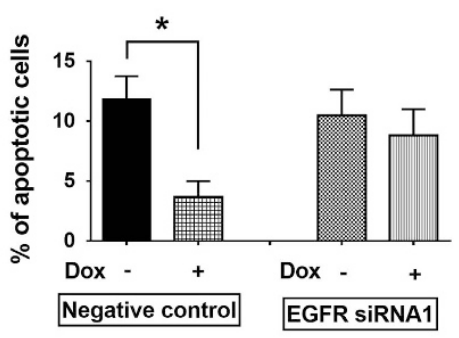

d

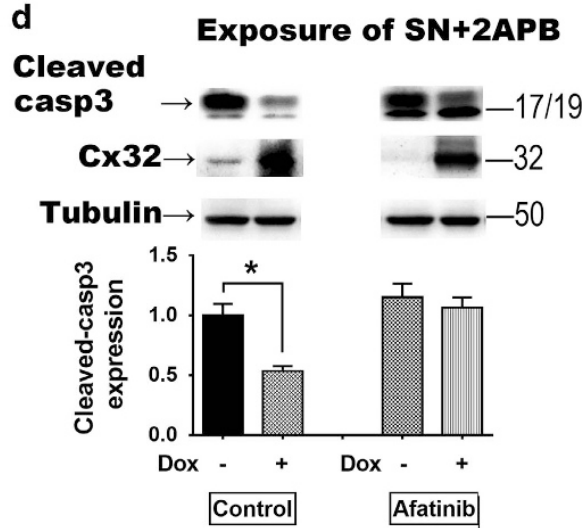

Figure 5 (a) In HeLa-Cx32 cells, EGFR siRNA sequence 1 effectively inhibited EGFR expression with and without doxycycline treatment $(n=3)$. (b) The anti-apoptotic effect of Cx32 expression was reversed by siRNA suppression of EGFR $(n=3)$. (c and d) The anti-apoptotic effect of Cx32 expression was reversed by EGFR signaling inhibitors erlotinib and afatinib $(n=3)$. Error bar: standard error. ${ }^{*} P<0.05 ; n=1$ represents an independent cell culture

evidence, our study demonstrates a relationship between Cx32 and EGFR in human specimens. In our pathological and in vitro studies, Cx32 was shown to be an active regulator of the EGFR pathway, which was necessary for its anti-apoptotic effects. The experiments using EGFR siRNA and EGFR pathway inhibitors show that the EGFR pathway is a critical element in $\mathrm{Cx} 32$ suppression of apoptosis. On this basis we propose that the EGFR pathway is a key mediator of the chemoprotective effects of non-junctional Cx32 in CaCx cells. Thus, all evidence-based findings in current study were summarized into an inferred diagram (Figure 6), and a serial of Cx32-related mechanisms were indicated.

Although $\mathrm{Cx32}$ tumor promoting effect was well supported by both clinical pathology and in vitro data, its role in $\mathrm{CaCx}$ cell's proliferation and metastasis is unclear. There is still a logical gap between in vitro apoptosis suppression and deteriorated prognostic variables to fill. A serial of xenograft animal model based experiments are preferable to be utilized for further study.

In conclusion, Cx32, traditionally tumor suppressive protein, was shown to be tumor protective against chemotherapy in vitro if it is prevented from forming GJs. This finding indicates that $\mathrm{Cx} 32$ can be a promising tumor marker to predict chemotherapeutic sensitivity of $\mathrm{CaCx}$. Cross-regional prospective clinical trials are required to test this idea. Moreover, as Cx32 expression is elevated in many cases of $\mathrm{CaCx}$, it might be feasible to therapeutically recover their GJIC to suppress tumor growth by manipulating the trafficking pathway. Further research focusing on recovering the $\mathrm{Cx}$ trafficking system in $\mathrm{CaCx}$ cell is needed.

\section{Materials and Methods}

Human cervix specimens and clinical data. Staging of $\mathrm{CaCx}$ was following the reported Federation International of Gynecology and Obstetrics (FIGO) system. ${ }^{42}$ Human cervix tissue samples were taken from patients who underwent total hysterectomy from 2012 to 2014 for treatment of CaCx (FIGO stage I, $n=148$; FIGO stage II, $n=165$ ) and benign multiple uterine fibroids ( $n=78$; used as normal cervix controls). After hysterectomy, cervix specimens were kept in liquid nitrogen for protein extraction or paraffin embedding. Clinical variables including age, ethnic group, maximum diameter of tumor, FIGO staging, lymph node metastasis, tumor emboli, differentiation, whole-layer infiltration, pelvic nerve invasion, recurrence and HPV infection were recorded for at least 2 years of following up. Expression and intracellular distribution of $\mathrm{C} \times 26, \mathrm{C} \times 30, \mathrm{C} \times 32$ and $\mathrm{C} \times 43$ were detected by western blot and immunohistochemistry. The study was approved by the Research Committee of Ethics in the Affiliated Cancer Hospital of Xinjiang Medical University.

Cell culture and authentication. As previously described, ${ }^{43} \mathrm{HeLa}-\mathrm{C} \times 32$ is a stable transgenic cell line with a tetracycline-inducible promoter, capable of constitutively expressing Cx32 when treated with doxycycline (Calbiochem, San Diego, CA, USA). C-33A and SiHa cells were purchased from American Type Culture Collection (Manassas, VA, USA). Cells were cultured in DMEM (C-33A in MEM) with $10 \%$ fetal bovine serum at $37^{\circ} \mathrm{C}, 5 \% \mathrm{CO}_{2}$, in a humidified incubator. As previously described, Hela-Cx32 cells were grown in above medium with $100 \mu \mathrm{g} / \mathrm{ml}$ of G418 (Calbiochem) and $200 \mu \mathrm{g} / \mathrm{ml}$ of hygromycin B (Calbiochem). HeLa-CX32 robustly expressed $\mathrm{C} \times 32$ after $48 \mathrm{~h}$ of doxycycline $(1 \mu \mathrm{g})$ treatment. For low-density cultures, 


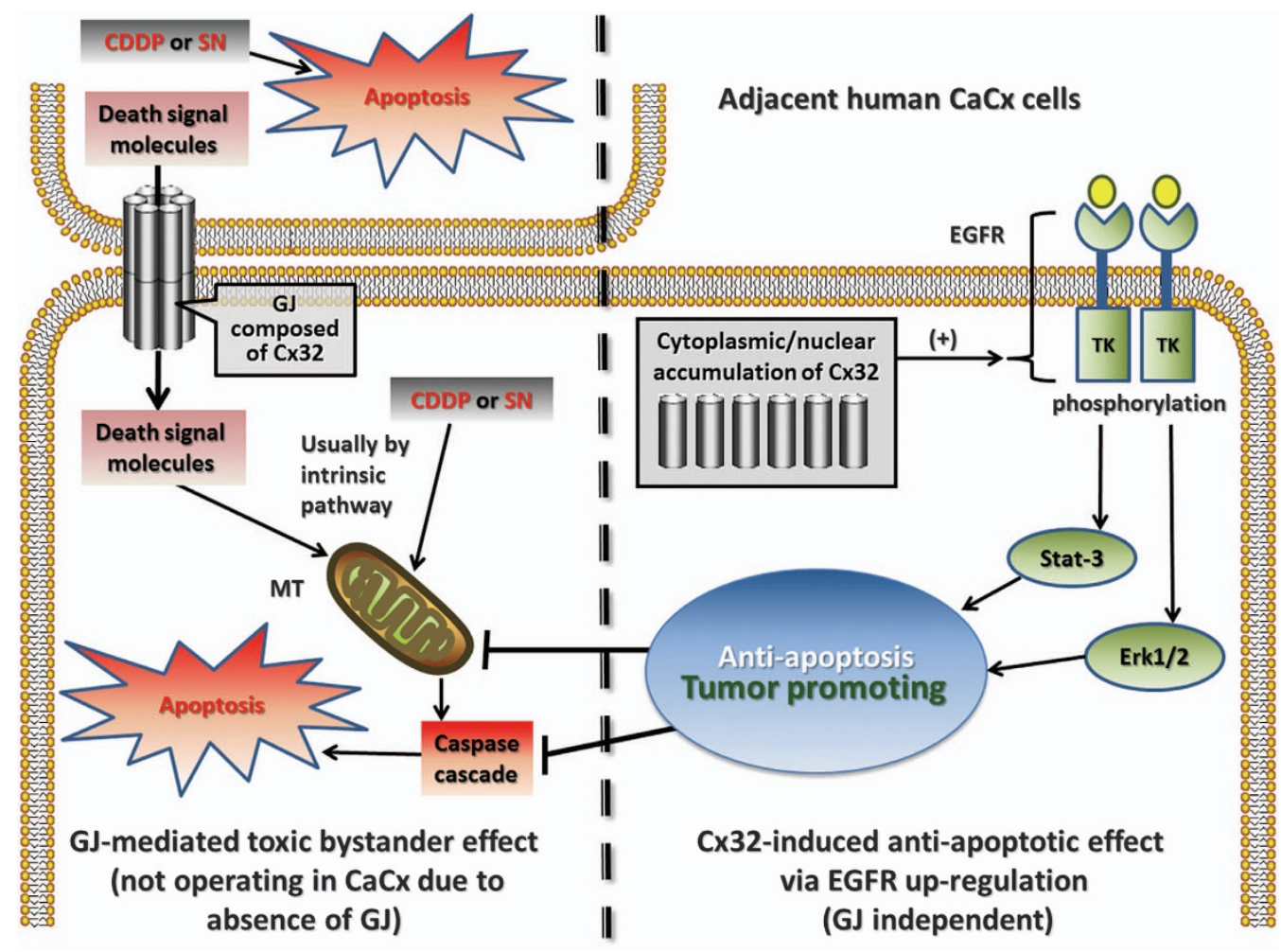

Figure 6 Diagram of the inferred Cx32 anti-apoptotic mechanism. in vitro, Cx32 suppressed SN/CDDP-induced apoptosis only after GJ function was inhibited, either pharmacologically or physically. This suggests that upregulated expression of $\mathrm{Cx} 32$ per se has an anti-apoptotic effect, in contrast to its GJ-dependent pro-apoptotic effect, with exposure to these chemotherapeutic agents. Because of the upregulated $\mathrm{C} \times 32$ and its non-junctional localization in $\mathrm{CaCx}$, the anti-apoptotic effect of $\mathrm{Cx} 32$ may dominate in cancer cells in vivo. Further, clinical-pathological data and in vitro findings indicate that the anti-apoptotic and tumor promoting effects involve the EGFR pathway in human CaCx cells. CDDP, Cisplatin; CaCx, cervical cancer; MT, mitochondria; SN, streptonigrin; TK, tyrosine kinase

$1 \times 10^{5}$ cells were seeded in a $150 \mathrm{~mm}$ dish to physically inhibit gap junction formation. For high-density cultures, $1 \times 10^{5}$ cells seeded in a well of $35 \mathrm{~mm}$ well plate to allow gap junction formation. The tool drugs including Cisplatin (CDDP), streptonigrin (SN), 18- $\alpha$-glycyrrhetinic acid (18 $\alpha$-GA), 2-aminoethoxydiphenyl-borate (2APB) were purchased from Sigma-Aldrich (St. Louis, MO, USA), whereas erlotinib and afatinib were from Selleck Chemicals (Houston, TX, USA).

Three $\mathrm{CaCx}$ cell lines (HeLa, SiHa, C-33A) were authenticated by short tandem repeat (STR) polymorphism analysis. DNA samples of cells were extracted and amplified with STR Multi-amplification Kit (PowerPlexTM 16 HS System, Promega Corporation, Madison, WI, USA) and assayed with ABI 3100 DNA Analyzer (Applied Biosystems, Thermofisher Scientific, Waltham, MA, USA). STR profiles of samples matched that of respective cell lines from ATCC and DSMZ data bank. No contamination of other human cell lines or other species was found in result.

DNA plasmid transfection and siRNA interference. Plasmid vectors of Cx32 (Product No. EX-A0514-M02-5) and Cx43 (Product No. EX-A0334-M02-5) were constructed by Genecopoeia (Rockville, MD, USA). Before DNA plasmid transfection, SiHa cells were seeded in 6 well plates and grown to $80 \%$ confluence. Following the manufacturer's instructions, each $10 \mu \mathrm{l}$ Lipofectamine 2000 (Invitrogen, Carlsbad, CA, USA) was mixed with DNA plasmid $(4 \mu \mathrm{g})$. The Lipofectamine-DNA compound was added to cell medium and kept for $6 \mathrm{~h}$ before change to normal medium. $48 \mathrm{~h}$ later, expression of $\mathrm{Cx} 32$ or $\mathrm{C} \times 43$ was assessed by real-time-qPCR and western blotting.

For siRNA transfection, C-33A or Hela-CX32 cells were grown to $30-50 \%$ confluence. Then the cells were transfected with respective siRNAs (Ribbon, Guangzhou, China) at a concentration of $50 \mathrm{nM}$ using Entranster R4000 transfection reagent (Engreen Biosystem, Beijing, China) according to the manufacturer's protocol. After $48 \mathrm{~h}$, suppression of Cx32 expression was detected by real-timeqPCR and western blotting. The sequences for the synthetic siRNAs Targeting CX32 (siCx32) were as follows:
SICX32_1: 5'-CCGGCATTCTACTGCCATT-3', siCx32_2: 5'-GGCTCACCAGCAACACATA-3', siCx32_3: 5'-GCAACAGCGTTTGCTATGA-3'.

The sequences for the synthetic siRNAs targeting EGFR (siEGFR) were as follows:

siEGFR_1: 5'-GGCTGGTTATGTCCTCATT-3',

siEGFR_2: 5'-CCTTAGCAGTCTTATCTAA-3',

siEGFR_3: 5'-GGAACTGGATATTCTGAAA-3'.

Extraction of total and nuclear protein. For total protein extraction, homogenized tissue $(50-100 \mathrm{mg})$ were rinsed with PBS and treated in ice-cold lysis-buffer. After ultra-sonication, the lysate solutions were centrifuged at $12000 \mathrm{rcf}$ for $30 \mathrm{~min}$ at $4{ }^{\circ} \mathrm{C}$. For nuclear protein extraction, a commercial kit (NE-PER Nuclear and Cytoplasmic Extraction Reagents, ThermoScientific, MA, USA) was applied following the manufacturer's instructions and previous method. ${ }^{44}$ Thus, the extracted supernatant (nucleoprotein) was moved into a pre-cooled tube after centrifugation (12000 rcf) at $4^{\circ} \mathrm{C}$ for $20 \mathrm{~min}$. Bio-Rad protein assay kit (Hercules, CA, USA) was used to measure protein concentration.

Western blot analysis. An equal amount $(20 \mu \mathrm{g})$ of each protein sample was added into SDS-PAGE gel for electrophoresis, and then transferred to a nitrocellulose membrane. The membranes were blocked with $5 \%(\mathrm{w} / \mathrm{v})$ skimmed milk in wash buffer (TBS and $0.05 \%$ Tween 20) for $1 \mathrm{~h}$. The respective primary antibodies were incubated with membranes overnight at $4{ }^{\circ} \mathrm{C}$. GAPDH, $\beta$-tubulin and $\beta$-actin were loading control markers for total protein and PCNA was that for nuclear protein. Primary antibodies against Cx32, Cx43, Cx26, Cx30 were purchased from Sigma-Aldrich (Respective product ID: C6344, C8093, SAB2500466, SAB2104321). Other primary antibodies against EGFR, ERK1/2, p-ERK1/2(Thr202/Tyr204), STAT3, p-STAT3 (Tyr705) and cleaved-caspase3 were obtained from Cell Signaling Technology (Danvers, MA, USA). Antibody dilution of Cx26, Cx30, Cx32, EGFR, ERK1/2, p-ERK1/2, STAT3, Caspase3, p-STAT3 was 
1:1000, dilution of $\mathrm{Cx} 43$ antibody was 1:5000, dilution of GAPDH, $\beta$-tubulin and $\beta$-actin was 1:10 000. The secondary antibody was incubated with membrane for $1 \mathrm{~h}$ at room temperature at a dilution half that of the primary antibodies. The immune-reactive bands were visualized by Amersham ECL Plus Western Blotting Detection Kit (GE Healthcare, Piscataway, NJ, USA), scanned and quantified by ImageQuant LAS 4000 and its associated software (GE). When processing band density data from human specimens and in vitro samples, ratio of target biomarker to respective loading control was calculated. Mean of the ratio from control bands were defined as ' 1 ' and fold changes of every sample's ratio to the mean were the finalized data.

Immunohistochemistry and immunofluorescence analysis. Normal cervix or $\mathrm{CaCx}$ tissues from patients were fixed with buffered formalin at $4{ }^{\circ} \mathrm{C}$ overnight, processed through graded ethanol solutions, and embedded in paraffin blocks. Tissue samples were sectioned to $10 \mu \mathrm{m}$ thick slices. The sections were dewaxed and dehydrated in gradient ethanol to water then autoclaved at $121^{\circ} \mathrm{C}$ for $10 \mathrm{~min}$ in $100 \mathrm{mM}$ citrate buffer $(\mathrm{pH} 6)$ for retrieving antigens prior to staining. The sections were treated with $3 \% \mathrm{H}_{2} \mathrm{O}_{2}$ for 30 min and $10 \%$ goat serum for $1 \mathrm{~h}$ at room temperature to block endogenous nonspecific reactivity. Primary antibodies of $\mathrm{C} \times 32$ and $\mathrm{C} \times 43$ were incubated with sections at dilution of 1:200 and $4{ }^{\circ} \mathrm{C}$ overnight before biotinylated secondary-antibodies were applied to label antigens for $30 \mathrm{~min}$ at $37^{\circ} \mathrm{C}$. The specific antigens were visualized by using the Vectastain ABC kit (Vector Laboratories, Burlingame, CA, USA) according to the manufacturer's protocol. Hematoxylin was used to counter-stain on the sections. Distribution of $\mathrm{C} \times 32$ and $\mathrm{C} \times 43$ was observed and captured under Olympus BX-51 microscope (Olympus, Tokyo, Japan).

For immunofluorescence imaging, the transient transfected SiHa cells were cultured in 16-well plate for $24 \mathrm{~h}$. After 3 times PBS rinse, the cells were fixed with $4 \%$ paraformaldehyde for $30 \mathrm{~min}$. Incubate with $0.1 \%$ Triton X100 for $20 \mathrm{~min}$, then block by $2 \%$ BSA for 30 min under room temperature. Thus, primary antibody (Cx32 and Cx43, dilute to 1:200) was applied and incubated overnight in $4^{\circ} \mathrm{C}$. After PBS rinse, incubated with Alexa Fluor555 conjugated secondary antibody (from ThermoFisher Scientific) (1:400) for $1 \mathrm{~h}$ under room temperature in dark hood. Phalloidin $(5 \mu \mathrm{g} / \mathrm{ml})$ and hoechst $(1 \mu \mathrm{g} / \mathrm{ml})$ were applied sequentially for actin and nuclear staining. After fully PBS rinse, immunofluorescence images of cells were captured under confocal microscope (LSM710, Carl Zeiss Jena, Germany).

Flow cytometry apoptosis detection assay. Hela-Cx32 cells were seeded in six-well plates and cultured with or without doxycycline for $48 \mathrm{~h}(80-100 \%$ confluence). The SiHa cells were transfected with plasmid of $\mathrm{Cx} 32, \mathrm{Cx} 43$ or vector for $48 \mathrm{~h}$; C-33A cells were transfected with siRNA Cx32 for $48 \mathrm{~h}$. Cells were incubated with SN $(1 \mu \mathrm{M})$ for $6 \mathrm{~h}$ or Cisplatin $(10 \mu \mathrm{M})$ for $24 \mathrm{~h}$. Afterward, the cells were washed three times in cold PBS and then trypsinized and harvested. Cells were re-suspended in binding buffer and after double staining with Annexin V-FITC and propidium iodide (PI) using the Annexin V-FITC apoptosis detection kit (Biotool, Houston, TX, USA) according to the manufacturer's protocol. The data were immediately analyzed by flow cytometry using the Expo32 Software (Beckman Coulter, 250 S. Kraemer Boulevard Brea, CA, USA) for determination of apoptotic cells.

Parachute dye-coupling assay. This assay was used to assess GJIC function as previously described. ${ }^{45}$ Cells were cultured to $80-90 \%$ confluence in 12-well dishes. Calcein-AM and CM-Dil were bought from Invitrogen. Donor cells were double-labeled with Calcein-AM (green fluorescence, GJ permeable) and $\mathrm{CM}$-Dil (red fluorescence, non-permeable) for $30 \mathrm{~min}$ at $37^{\circ} \mathrm{C}$. Cells were rinsed, trypsinized and seeded onto the receiver cells at a 1:150 donor/receiver ratio then incubated for $4 \mathrm{~h}$ at $37^{\circ} \mathrm{C}$. Using a fluorescence microscope (Olympus IX71, Tokyo, Japan), the average number of receiver cells (green fluorescence) around every donor cell (both green and red fluorescence) was recorded as an index of GJIC function.

Real-time-qPCR. The total RNA was extracted using the Hipure Total RNA Kits (Magen, Guangzhou, Guangdong, China) according to the manufacturer's instructions. The collected RNA was reverse-transcribed using the reverse transcription kit (Transgen Biotech, Beijing, China) and the resulting CDNA was subjected to qPCR and RT-PCR reactions performed in a final volume of $20 \mu \mathrm{l}$ using the quantitative real-time PCR kit (Transgen Biotech) according to the manufacturers' instructions. All primer sequences in this study were acquired from PrimerBank (Massachusetts General Hospital, Boston, MA, USA), ${ }^{46}$ including: Cx32 (PrimerBank ID 195222738c1), Cx43 (PrimerBank ID 122939163c1) and EGFR
(PrimerBank ID 41327735c1). Resulting CT value for every target gene in every sample was normalized to the respective value of GAPDH to acquire the relative expression data.

Statistical analysis. Every in vitro experiment was performed with a minimum of three independent cell cultures. Statistical analysis utilized Graphpad Prism 6.0 software. Parametric clinical variables are presented as mean and $95 \%$ confidence interval. Parametric data were analyzed by one-way ANOVA or student's t-test, nonparametric data were analyzed by Fisher's exact test, and correlation between Cx32 and EGFR expression was analyzed by Pearson's correlation analysis. Statistical significance was defined as $P<0.05$ and all tests were two sided.

Data availability. All supporting data in this work are also available in figshare. URL: https://figshare.com/s/575ba44ead4c94daccbb DOI: 10.6084/m9.figshare.4543066

\section{Conflict of Interest}

The authors declare no conflict of interest.

Acknowledgements. This work was supported in part by below: the Joint Fund of the National Nature Science Foundation of China (contract no. U1303221), the National Natural Science Foundation of China (contract no. 81373439 and 81473234), the grant for the construction of technique plate for evaluation of the pharmacodynamics of new drugs in Xinjiang from the Department of Science and Technology of Xinjiang Province (contract no. 201233150).

1. Kar R, Batra N, Riquelme MA, Jiang JX. Biological role of connexin intercellular channels and hemichannels. Arch Biochem Biophys 2012; 524: 2-15.

2. Kumar NM, Gilula NB. The gap junction communication channel. Cell 1996; 84: 381-388.

3. Mehta PP, Bertram JS, Loewenstein WR. Growth inhibition of transformed cells correlates with their junctional communication with normal cells. Cell 1986; 44: 187-196.

4. Loewenstein WR KY. Intercellular communication and the control of tissue growth: lack of communication between cancer cells. Nature 1966; 209: 1248-1249.

5. Kanczuga-Koda LKM, Sulkowski S, Wincewicz A, Zalewski B, Sulkowska M. Gradual loss of functional gap junction within progression of colorectal cancer_a shift from membranous CX32 and CX43 expression to cytoplasmic pattern during colorectal. In Vivo 2010; 24 : 101-107.

6. Steinhoff I, Leykauf K, Bleyl U, Durst M, Alonso A. Phosphorylation of the gap junction protein connexin43 in CIN III lesions and cervical carcinomas. Cancer letters 2006; 235 : 291-297.

7. Tomakidi P, Cheng H, Kohl A, Komposch G, Alonso A. Connexin 43 expression is downregulated in raft cultures of human keratinocytes expressing the human papillomavirus type 16 E5 protein. Cell Tissue Res 2000; 301: 323-327.

8. Bruzzone R, White TW, Paul DL. Connections with connexins: the molecular basis of direct intercellular signaling. Eur J Biochem 1996; 238: 1-27.

9. Huang RP, Hossain MZ, Huang R, Gano J, Fan Y, Boynton AL. Connexin 43 (cx43) enhances chemotherapy-induced apoptosis in human glioblastoma cells. Int J Cancer 2001; 92: $130-138$.

10. Hong $X$, Wang $Q$, Yang $Y$, Zheng S, Tong X, Zhang S et al. Gap junctions propagate opposite effects in normal and tumor testicular cells in response to cisplatin. Cancer Lett 2012; 317: 165-171.

11. Zhang Y, Tao L, Fan L, Peng Y, Yang K, Zhao $Y$ et al. Different gap junction-propagated effects on cisplatin transfer result in opposite responses to cisplatin in normal cells versus tumor cells. Sci Rep 2015; 5: 12563.

12. Fujimoto $E$, Sato $H$, Shirai $S$, Nagashima $Y$, Fukumoto $K$, Hagiwara $H$ et al. Connexin32 as a tumor suppressor gene in a metastatic renal cell carcinoma cell line. Oncogene 2005; 24 : 3684-3690.

13. Fujimoto EYT, Sato H, Hagiwara K, Yamasaki H, Shirai S, Fukumoto K et al. Cytotoxic effect of the Her2_Her1 inhibitor PKI166 on renal cancer cells expressing the connexin 32 gene. J Pharmacol Sci 2005; 97: 294-298.

14. Hattori Y, Fukushima M, Maitani Y. Non-viral delivery of the connexin 43 gene with histone deacetylase inhibitor to human nasopharyngeal tumor cells enhances gene expression and inhibits in vivo tumor growth. Int J Oncol 2007; 30: 1427-1439.

15. Ezumi K, Yamamoto H, Murata K, Higashiyama M, Damdinsuren B, Nakamura $Y$ et al. Aberrant expression of connexin 26 is associated with lung metastasis of colorectal cancer. Clin Cancer Res 2008; 14: 677-684.

16. Tang BPZ, Yu PW, Yu G, Qian F, Zeng DZ, Zhao YL et al. Aberrant expression of Cx43 is associated with the peritoneal metastasis of gastric cancer and $\mathrm{C} \times 43$ mediated gap junction enhances gastric cancer cell. PLOS ONE 2013; 8: e74527.

17. Kanczuga-Koda L, Sulkowski S, Lenczewski A, Koda M, Wincewicz A, Baltaziak M et al. Increased expression of connexins 26 and 43 in lymph node metastases of breast cancer. J Clin Pathol 2006; 59: 429-433. 
18. Li Q, Omori Y, Nishikawa Y, Yoshioka T, Yamamoto $Y$, Enomoto K. Cytoplasmic accumulation of connexin32 protein enhances motility and metastatic ability of human hepatoma cells in vitro and in vivo. Int J Cancer 2007; 121: 536-546.

19. Lamiche C, Clarhaut J, Strale PO, Crespin S, Pedretti N, Bernard FX et al. The gap junction protein $\mathrm{Cx} 43$ is involved in the bone-targeted metastatic behaviour of human prostate cancer cells. Clin Exp Metastasis 2012; 29: 111-122.

20. Murphy SF, Varghese RT, Lamouille S, Guo S, Pridham KJ, Kanabur P et al. Connexin 43 inhibition sensitizes chemoresistant glioblastoma cells to temozolomide. Cancer Res 2016; 76: 139-149.

21. Munoz JL, Rodriguez-Cruz V, Greco SJ, Ramkissoon SH, Ligon KL, Rameshwar P. Temozolomide resistance in glioblastoma cells occurs partly through epidermal growth factor receptor-mediated induction of connexin 43. Cell Death Dis 2014; 5: e1145.

22. Zhao B, Zhao W, Wang Y, Xu Y, Xu J, Tang K et al. Connexin32 regulates hepatoma cell metastasis and proliferation via the p53 and Akt pathways. Oncotarget 2015; 6: 10116-10133

23. Smith JS, Brewer NT, Saslow D, Alexander K, Chernofsky MR, Crosby R et al. Recommendations for a national agenda to substantially reduce cervical cancer. Cancer Causes Control 2013; 24: 1583-1593.

24. Forhan SE, Godfrey CC, Watts DH, Langley CL. A systematic review of the effects of visual inspection with acetic acid, cryotherapy, and loop electrosurgical excision procedures for cervical dysplasia in HIV-infected women in low- and middle-income countries. J Acquir Immune Defic Syndr 2015; 68: S350-S356.

25. Wagner M, Bennetts L, Patel H, Welner S, de Sanjose S, Weiss TW. Global availability of data on HPV genotype-distribution in cervical, vulvar and vaginal disease and genotype-specific prevalence and incidence of HPV infection in females. Infect Agent Cancer 2015; 10: 13.

26. de Sanjose S, Quint WG, Alemany L, Geraets DT, Klaustermeier JE, Lloveras B et al. Human papillomavirus genotype attribution in invasive cervical cancer: a retrospective cross-sectional worldwide study. Lancet Oncol 2010; 11: 1048-1056.

27. Oelze I, Kartenbeck J, Crusius K, Alonso A. Human papillomavirus type 16 E5 protein affects cell-cell communication in an epithelial cell line. J Virol 1995; 69: 4489-4494.

28. Aasen T, Graham SV, Edward M, Hodgins MB. Reduced expression of multiple gap junction proteins is a feature of cervical dysplasia. Mol Cancer 2005; 4: 31.

29. Kameritsch P, Khandoga N, Pohl U, Pogoda K. Gap junctional communication promotes apoptosis in a connexin-type-dependent manner. Cell Death Disease 2013; 4: e584.

30. Stains JP, Civitelli R. Gap junctions regulate extracellular signal-regulated kinase signaling to affect gene transcription. Mol Biol Cell 2005; 16: 64-72.

31. Cao YW, Lu TC, Pan XL, Li F, Zhong HH, Sun Y et al. Correlation of expression of connexin to growth and progression of cervical carcinoma in situ. Ai Zheng 2005; 24: 567-572.

32. Wang HYS, Xu J, Xu X, He H, Ronca F, Ting AE et al. Isolation of streptonigrin and its novel derivative from Micromonospora as inducing agents of p53-dependent cell apoptosis. $J$ Nat Prod 2002; 65: 721-724.

33. Eskander RN, Tewari KS. Chemotherapy in the treatment of metastatic, persistent, and recurrent cervical cancer. Curr Opin Obstet Gynecol 2014; 26: 314-321.

34. Spray DC, Hanstein R, Lopez-Quintero SV, Stout RF Jr, Suadicani SO, Thi MM. Gap junctions and bystander effects: good samaritans and executioners. Wiley Interdiscip Rev Membr Transp Signal 2013; 2: 1-15.

35. Tong X, Dong S, Yu M, Wang Q, Tao L. Role of heteromeric gap junctions in the cytotoxicity of cisplatin. Toxicology 2013; 310: 53-60.
36. Carette D, Gilleron J, Chevallier D, Segretain D, Pointis G. Connexin a check-point component of cell apoptosis in normal and physiopathological conditions. Biochimie 2014; 101: 1-9.

37. Behrens J, Kameritsch P, Wallner S, Pohl U, Pogoda K. The carboxyl tail of Cx43 augments p38 mediated cell migration in a gap junction-independent manner. Eur J Cell Biol 2010; 89: 828-838.

38. Langlois S, Cowan KN, Shao Q, Cowan BJ, Laird DW. The tumor-suppressive function of Connexin43 in keratinocytes is mediated in part via interaction with caveolin-1. Cancer Res 2010; 70: 4222-4232.

39. Dang X, Doble BW, Kardami E. The carboxy-tail of connexin- 43 localizes to the nucleus and inhibits cell growth. Mol Cell Biochem 2003; 242: 35-38.

40. Kardami E, Dang X, lacobas DA, Nickel BE, Jeyaraman M, Srisakuldee W et al. The role of connexins in controlling cell growth and gene expression. Prog Biophys Mol Biol 2007; 94: 245-264.

41. Sulkowski S, Kanczuga-Koda L, Koda M, Wincewicz A, Sulkowska M. Insulin-like growth factor-I receptor correlates with connexin 26 and $B c l-x L$ expression in human colorectal cancer. Ann NY Acad Sci 2006; 1090: 265-275.

42. Petru E, Luck HJ, Stuart G, Gaffney D, Millan D, Vergote I et al. Gynecologic cancer intergroup (GCIG) proposals for changes of the current FIGO staging system. Eur J Obstet Gynaecol Reprod Biol 2009; 143: 69-74.

43. Koreen IV, Elsayed WA, Liu YJ, Harris AL. Tetracycline-regulated expression enables purification and functional analysis of recombinant connexin channels from mammalian cells. Biochem J 2004; 383: 111-119.

44. Zhu M, Du J, Liu AD, Holmberg L, Chen SY, Bu D et al. L-cystathionine inhibits oxidized low density lipoprotein-induced THP-1-derived macrophage inflammatory cytokine monocyte chemoattractant protein-1 generation via the NF-kappaB pathway. Sci Rep 2015; 5: 10453.

45. Goldberg GS, Bechberger JF, Naus CC. A pre-loading method of evaluating gap junctional communication by fluorescent dye transfer. Biotechniques 1995; 18: 490-497.

46. Spandidos A, Wang X, Wang $H$, Seed B. PrimerBank: a resource of human and mouse PCR primer pairs for gene expression detection and quantification. Nucleic Acids Res 2010; 38 : D792-D799.

(c) (i) Cell Death and Disease is an open-access journal published by Nature Publishing Group. This work is licensed under a Creative Commons Attribution 4.0 International License. The images or other third party material in this article are included in the article's Creative Commons license, unless indicated otherwise in the credit line; if the material is not included under the Creative Commons license, users will need to obtain permission from the license holder to reproduce the material. To view a copy of this license, visit http://creativecommons.org/licenses/by/4.0/

(C) The Author(s) 2017

Supplementary Information accompanies this paper on Cell Death and Disease website (http://www.nature.com/cddis) 